\title{
MECHANISM OF ENFORCEMENT AND EXECUTION OF MUSLIM MAINTENANCE ORDER: COURT - BASED SYSTEM
}

\author{
Jazilah Mohd Saad@Mat Saud; ${ }^{*}$ Afridah Abbas; ${ }^{* *}$ \\ Noraini Hashim; ${ }^{* * *} \&$ Saodah Wok ${ }^{* * * *}$
}

\begin{abstract}
The weaknesses of the enforcement and execution of a court order always become the reason for noncompliance with court orders issued by the Syariah Court. In other words, the effectiveness of enforcement mechanisms enhances compliance with orders issued by the Syariah Court. Many looked at the weaknesses of enforcement as the weaknesses of the Syariah court as the agency for implementing
\end{abstract}

\footnotetext{
* PhD candidate, Ahmad Ibrahim Kulliyyah of Laws, International Islamic University Malaysia. E-mail: jazilahsaad@yahoo.com/ jazilah@esyariah.gov.my. The researcher would like to thank Syariah Judiciary Department of Malaysia (JKSM), Chief Registrar of Penang, Federal Territories, Sarawak, Negeri Sembilan and Terengganu for the assistance in data collection and also FSD officer for their willingness to be the research respondents.

** $\quad$ Assistant Professor, Ahmad Ibrahim Kulliyyah of Laws, International Islamic University Malaysia. E-mail: afridah@iium.edu.my.

*** Assistant Professor, Ahmad Ibrahim Kulliyyah of Laws, International Islamic University Malaysia. E-mail: Noorainimh@iium.edu.my. Associate Professor, Department of Communication, International Islamic University Malaysia. E-mail: wsaodah@iium.edu.my.
} 
justice and thus undermining the position of the Islamic law. However, very little attention has been given in the literature as regards what constitutes the mechanism of enforcement and execution of a maintenance order in the Syariah Court. Hence, the purpose of this article is to examine the mechanism used pertaining to non-compliance maintenance orders. The content analysis approach was used as it is appropriate to identify the mechanism used by the selected Syariah courts in settling the enforcement and execution cases. Through the content analysis method, the background of the cases as well as the approach of the court players were identified, respectively. The data from the study then were presented in descriptive form to explain the frequency and the percentage of variables studied. The study suggests that the process of giving judgment relating to maintenance should be improved. In addition, the assimilisation between non-legal and legal processes should be well organised to ensure the effectiveness of the enforcement and execution processes. The weaknesses found should be addressed in future studies to identify the best method for better implementation.

Keywords: enforcement; maintenance order; Syariah Court; judgment creditor; judgment debtor.

\title{
MEKANISMA PENGUATKUASAAN DAN PELAKSANAAN PERINTAH NAFKAH ORANG ISLAM: SISTEM BERASASKAN MAHKAMAH
}

\begin{abstract}
ABSTRAK
Kelemahan-kelemahan di dalam penguatkuasaan dan pelaksanaan sesuatu perintah mahkamah sentiasa menjadi penyebab kepada ketidakpatuhan
\end{abstract}


terhadap perintah-perintah mahkamah yang dikeluarkan oleh Mahkamah Syariah. Dalam ertikata lain, keberkesanan mekanisma penguatkuasaan meningkatkan pematuhan terhadap perintah yang dikeluarkan oleh Mahkamah Syariah. Kelemahan penguatkuasaan dilihat sebagai kelemahan Mahkamah Syariah itu sendiri sebagai sebuah agensi untuk melaksanakan keadilan yang mana turut memberi kesan kepada undang-undang Islam. Walaubagaimanapun, tidak banyak literatur yang membincangkan mengenai apa yang dikatakan sebagai mekanisma penguatkuasaan dan pelaksanaan perintah berkaitan nafkah di Mahkamah Syariah. Oleh itu, artikel ini bertujuan untuk mengkaji mekanisma yang digunakan sekiranya berlaku ketidakpatuhan terhadap perintah-perintah berkaitan nafkah. Pendekatan analisis kandungan digunakan kerana ianya sesuai bagi mengenalpasti mekanisma yang digunakan oleh Mahkamah-mahkamah Syariah terpilih dalam menyelesaikan kes-kes berkaitan penguatkuasaan dan pelaksanaan. Melalui metode ini, latarbelakang kes dan juga pendekatan pegawai-pegawai mahkamah dikenalpasti. Data yang diperolehi daripada kajian kemudiannya dibentangkan dalam bentuk deskriptif bagi menjelaskan frekuensi dan peratusan varians yang dikaji. Kajian mencadangkan bahawa proses bagaimana sesuatu perintah berkaitan dengan nafkah itu dikeluarkan hendaklah dipertingkatkan. Seterusnya, asimilasi di antara proses bukan perundangan dan perundangan sepatutnya lebih tersusun untuk memastikan keberkesanan proses penguatkuasaan dan pelaksanaan. Kelemahankelemahan yang dikenalpasti hendaklah dinyatakan di dalam kajian akan datang bagi mengenalpasti metode yang terbaik bagi pelaksanaan yang lebih baik. 
Kata kunci: penguatkuasaan, perintah nafkah, Mahkamah Syariah, pemiutang penghakiman, penghutang penghakiman.

\section{INTRODUCTION}

As far as Islamic law in Malaysia is concerned, all matters relating to family law, including matters related to the application for a maintenance order is subject to the states' jurisdiction based on shariah law. All orders for maintenance requires application to a court of competent jurisdiction subject to the residence of the applicant. If the maintenance order is not complied with, it requires an enforcement action and this action should only be undertaken by the Shariah Court that issued the order. This court mechanism can undertake a variety of actions as provided by shariah procedural law. This article will examine the mechanism used by the Shariah Court pertaining to enforcement and execution of maintenance orders.

The objectives of this quantitative study are to analyse the mechanism used in enforcement and execution of maintenance orders procedures and to examine the implementation of the enforcement and execution mechanism based on the court based system. This research will thus answer the following questions:

1. What are the types of maintenance orders that require enforcement and execution action?

2. What kind of payment that needs enforcement and execution action?

3. What is the reason for the application and how long does it take the plaintiff to commence legal action against the defendant?

4. What are the processes of enforcement and execution action?

5. What are the judicial decisions for the enforcement and execution action and how long does it take to resolve the legal enforcement action? 


\section{LITERATURE REVIEW}

Review of the literature has found that researchers and writers in the past have written extensively on the legal procedure that relates to enforcement and execution of orders. However, few studies have been made on the enforcement and execution of court orders especially regarding to its mechanism. From the literature, enforcement based on court system seems to be the only method applicable to enforce a judgment or order in the Shariah Court in Malaysia. ${ }^{1}$

A study done by Zaini Nasohah (2007) has discussed on the enforcement and execution of maintenance orders in the State of Selangor. The study showed that there are several main problems of enforcement and execution of maintenance orders in Selangor that need further consideration. Most of the problems identified are related to human factors either coming from the parties, the courts, Religious Officers and also law and regulation pertaining to enforcement. ${ }^{2}$ In support of this issue of maintenance, Kamalruazmi Ismail, and Fatimah Bt Sulaiman (2003) have shown that cases related to non-compliance of court orders still continued particularly in maintenance cases. ${ }^{3}$

Meanwhile a socio-legal study on the financial rights of Muslim divorced women and its effect on family welfare by Muslihah Binti Hasbullah @ Abdullah)20054 indicated that the effective enforcement of a court order as a significant factor that might protect the economic welfare of the woman after divorce. She also suggested tougher enforcement action by prosecuting the unruly ex-husband and the

1 Muslihah Binti Hasbullah @ Abdullah, “A Socio-Legal Study on Financial Rights of Muslim Divorced Women and Its Effects On Family Welfare,” PhD Thesis IIUM 2009 at 219.

2 Marhayu Binti Abdul Jamal 2010, "Masalah Penguatkuasaan Perintah Mahkamah Dalam Kes Mal di Mahkamah Tinggi Syariah Kuantan Pahang,” Master Disertation University Malaya.

$3 \quad$ KamalruAzmi Ismail, "Penguatkuasaan Dan Pelaksanaan Perintah Mahkamah Syariah Negeri Terengganu, Satu Kajian Dari Aspek Keberkesanan," Kuala Lumpur, University Of Malaya 2003 and Fatimah Bt Sulaiman, Tahap Kepatuhan Terhadap Keputusan Mahkamah Syariah Dalam Kes Nafkah: Kajian Kes Terengganu, http: citutrg.blogspot.com.

$4 \quad$ Muslihah Binti Hasbullah @ Abdullah, ibid. 
establishment of an administrative machinery to assist divorced women to effectively enforce the court order. In addition, Aliyyah (2007) discovered the main obstacle in enforcing the maintenance order is the negative attitudes of the parties. The whereabouts of the ex-husband is crucial in determining whether the maintenance order could be enforced because all modes of executing the order would require information of the husband's whereabouts. ${ }^{5}$

Literature from Western countries reflect that, under Civil Contempt Sanctions, orders are typically enforced through a mechanism called a Rule to Show Cause, in which a party seeks civil contempt sanctions for the other party's willful violation of a court order. ${ }^{6}$ Enforcement is often associated with authority and violence. ${ }^{7}$ Overall enforcement mechanisms fall into two categories, either negative or positive. Positive enforcement mechanisms encourage compliance with an agreement by providing rewards or incentives, while negative enforcement mechanisms encourage compliance by threatening and using punishments or disincentives. ${ }^{8}$ This concept usually applies in the international system.

A previous study on the adherence of child support payment however suggested that compliance with the order depends on fathers' perceptions of fairness of support orders. ${ }^{9}$ The paper examines whether perceptions of fairness motivate fathers to pay child support and whether perceptions of fairness interact with routine income withholding in collecting payments. Using a study of 392 non-resident fathers who filed for divorce between 1986 and 1988 in the state of Wisconsin, the researcher found that both perceived fairness and income withholding

$5 \quad$ Aliyah Bt Abdullah, "Enforcement Of Maintenance Order In The Melaka Syariah Court,” Institute Penyelidikan Pembangunan Dan Pengkomersilan University Teknologi Mara Shah Alam Selangor. June 2007, http://eprints.ptar.uitm.edu.my/4237/ILP_ALIYAH_ABDULLAH 07-24.pdf retrieved on 23/2/2012.

$6 \quad$ Ibid.

7 Jullian Quellet, http://www.beyondintractability.org/essay/ enforcement_mechanisms/retrieved on 22/4/2011.

8 Ibid.

$9 \quad$ Lin, I.F., "Perceived Fairness and Compliance With Child Support Obligations,” (2000), Journal of Marriage and Family, 62: 388-398. doi: 10.1111/j.1741-3737.2000.00388 retrieved on 22/4/2011. 
increase fathers' compliance with child support obligations. The effects of these two strategies on compliance are not correlated. However, if fathers think their child support orders are fair, the use of routine income withholding does not add to compliance. ${ }^{10}$ Other studies show that there is a relationship between socioeconomic status, mediation, and suitability for mediation with child support compliance. ${ }^{11}$

From a brief literature review, no single study has covered the mechanism of the enforcement and execution of court order in Shariah Court. Even though past research has stated that the weaknesses of the enforcement and execution of a court order becomes one of the reasons for the occurrence of non-compliance with court orders issued by the Shariah Court.

\section{METHODOLOGY}

The design of this study is purely descriptive. For this purpose, content analysis of the court documents that is the case file and the implementation of the enforcement of maintenance orders were applicable. This method was applied as it is appropriate to identify the mechanism used by the selected Shariah Courts in settling the enforcement and execution cases. Through the content analysis method the background of the cases as well as the approach of the court players were identified respectively. The data from the study then were presented in descriptive statistics to explain the frequency and the percentage of variables studied.

For the purpose of this study, cases of enforcement of maintenance order in the Shariah Courts in five states ${ }^{12}$ had been randomly selected. According to statistical experts, if the study involves

\footnotetext{
$10 \quad$ Ibid.

11 Tishler, C.L., Landry-Meyer, L., \& Bartholomae, S. "Mediation and Child Support: An Effective Partnership,” (2003) Journal of Divorce \& Remarriage, 38, 129-145. As cited in Scot Schraufnagel and Quan Li Testing the Suitability of Mediation of Child Support Orders in Title IV-D Cases Research on Social Work Practice 2010 http:// rsw.sagepub.com/content/20/2/212 retrieved on March 18, 2012.

12 Five states are Federal Teritory, Negeri Sembilan, Pulau Pinang, Terengganu and Sarawak. All states were selected based on the region.
} 
the calculation of statistical, the sample submitted must contain at least 150 subjects. ${ }^{13}$ Thus, for this study, 500 files from five states were analyzed. It means that from each state, approximately 100 files were analyzed.

One basic reason for choosing the five states is that it may not be possible to collect information from 102 Shariah Courts in all the 13 states all over Malaysia. Therefore, five states were selected based on the regional location in Malaysia. Random samples of court cases were taken from the Shariah courts of each state for this study. The study examined the cases of enforcement and execution of the order resolved from 2005 to 2010.

The study was based on the formation of the checklist. The checklist form was divided into six sections. ${ }^{14}$

\section{Section 1: The Acquisition of the Data}

This section comprised of two checklists. The checklists were intended to analyse the information about the locality of the data, which included the state and type of the court.

\section{Section II: Cases Information}

This section was intended to explain the background of the cases. It comprised of eight types of information which included type of application, type of cases, reason for application, type of order, channel of payment, method of payment period between judgment and application for enforcement, and the information about the endorsement of the order.

13 Sabitha Marican Penyelidikan Sains Sosial:Pendekatan Pragmatic (Selangor: Du System Sdn Bhd 2009) at 132.

14 The analysis of the court's files is pertaining to the information of the acquisition, case information, background of the parties, background of the proceeding, judgment and authorities used in the judgment. 


\section{Section III: Background of the Parties}

In this section, the checklists were intended to gather the information about the background of the parties namely, the plaintiff and the defendant. The characteristics of the information included were age, type of employment, monthly income, number of children, marital status, and level of education.

\section{Section IV: Background of the Proceeding}

This section comprised of the background of the proceeding either pretrial or trial. The checklist intended to find out the information about the process of mediation, summons, notice, warrant of arrest, and defendant means test.

\section{Section V: Judgment}

This section described the information of the judgment and the period taken for case settlement.

\section{Section VI: Authorities}

In this section, the checklist was formed to analyse the authorities referred to by judges.

\section{FINDINGS}

Results are presented in the form of table 1 to table 7 to ease the discussion. 


\section{Profile of Judgment Debtor and Judgment Creditor to Apply for Enforcement and Execution of Maintenance Order}

The profile of the judgment debtor and the judgment creditor is very difficult to access because most of the enforcement and execution of the maintenance order cases, affidavit and statement of claim, do not clearly state the profile of the judgment debtor and the judgment creditor. Furthermore, the judgment debtor's financial capability is not mentioned in the application even though information is very important to be declared in the process of enforcement and execution of the court order. Only in the Federal Territory Syariah Court provides a specific registration form for the judgment creditor to fill up the necessary information about the judgment creditor and judgment debtor. Thus, the judgment debtors' and the judgment creditors' profiles and all the information needed will be provided in the registration form. Profiles of the judgment debtor and the judgment creditor from the data are displayed below in Table 1. 
Table 1

Demographic characteristics of judgment creditor/ Judgment debtor

\begin{tabular}{|c|c|c|c|c|}
\hline \multirow[t]{2}{*}{ Demographic characteristics } & \multicolumn{2}{|c|}{ Judgment Creditor } & \multicolumn{2}{|c|}{ Judgment Debtor } \\
\hline & Frequency & Percentage & Frequency & Percentage \\
\hline \multicolumn{5}{|l|}{ Age (years) } \\
\hline Less than 20 & 1 & 0.3 & 0 & 0 \\
\hline $21-30$ & 43 & 12.1 & 33 & 9.4 \\
\hline $31-40$ & 161 & 45.5 & 124 & 34.9 \\
\hline $41-50$ & 118 & 33.3 & 138 & 38.9 \\
\hline $51-60$ & 25 & 7.1 & 48 & 13.5 \\
\hline $61-70$ & 6 & 2.0 & 9 & 2.5 \\
\hline Total & 354 & 100 & 352 & 100 \\
\hline Mean & 34 & & 36 & \\
\hline SD & 8.9 & & 9.9 & \\
\hline \multicolumn{5}{|l|}{ Type of employment } \\
\hline Private & 78 & 30.2 & 118 & 44.9 \\
\hline Self employed & 32 & 12.4 & 66 & 25.1 \\
\hline Government & 38 & 14.7 & 64 & 24.3 \\
\hline Retiree & 3 & 1.2 & 9 & 3.4 \\
\hline Not working & 0 & 0 & 5 & 1.9 \\
\hline Others (eg:student) & 2 & 1.0 & 1 & 0.4 \\
\hline Housewife & 105 & 41.0 & 0 & 0 \\
\hline Total & 258 & 100 & 263 & 100 \\
\hline \multicolumn{5}{|l|}{ Monthly income (RM) } \\
\hline Less than RM1000 & 33 & 43.4 & 13 & 16.0 \\
\hline RM1001-RM2000 & 22 & 29.0 & 27 & 33.3 \\
\hline RM2001-RM3000 & 13 & 17.1 & 15 & 18.5 \\
\hline RM3001-RM4000 & 3 & 3.9 & 10 & 12.4 \\
\hline RM4001-RM5000 & 1 & 1.2 & 3 & 3.7 \\
\hline RM5001-RM6000 & 3 & 3.9 & 2 & 2.5 \\
\hline RM6001and above & 1 & 1.3 & 11 & 13.5 \\
\hline Total & 76 & 100 & 81 & 100 \\
\hline Mean & 3400 & & 3700 & \\
\hline SD & 896 & & 998 & \\
\hline \multicolumn{5}{|l|}{ Dependant } \\
\hline No child & 1 & 0.3 & 0 & 0 \\
\hline One child & 37 & 10.4 & 34 & 9.6 \\
\hline 2 children & 81 & 22.8 & 80 & 22.5 \\
\hline 3 children & 107 & 30.1 & 103 & 29.0 \\
\hline 4 children & 56 & 15.8 & 62 & 17.5 \\
\hline 5 children & 73 & 20.6 & 76 & 21.4 \\
\hline Total & 355 & 100 & 355 & 100 \\
\hline Mean & 3.2 & & 3.2 & \\
\hline SD & 2.5 & & 1.2 & \\
\hline \multicolumn{5}{|l|}{ Marital status } \\
\hline Married & 26 & 7.4 & 57 & 16.6 \\
\hline Divorced & 326 & 92.6 & 299 & 87.1 \\
\hline Total & 352 & 100 & 343 & 100 \\
\hline
\end{tabular}




\section{Judgment Creditor and Judgment Debtor by Age}

Almost half (45.5\%) of the judgment creditors were aged 31-40 years old followed by nearly one-third (33.3\%) who were $41-50$ years old. For the age of 21-30 and 51-60 years old, their percentage are at $12.1 \%$ and $7.0 \%$ respectively. Meanwhile, more than one-third of the judgment debtors; (38.9\%) are in the age of 41-50 years old, followed by 31-40 years old which is about $34.9 \%$. About one fifth (13.5\%) of the respondents are in between the age of 51-60 years old.

\section{Judgment Creditor and Judgment Debtor by Occupational Status}

Among of the judgment creditors for enforcement and execution are housewives, which indicates $41.0 \%$. On the other hand, nearly one third (30.2\%) of the judgment creditors are working in private sectors whereas a small number of them are working in the government sector (14.7\%). Conversely, for the judgment debtor, most of them are working in either private, government or self employed. The data indicates that more than one-third (44.9\%) of the respondents are working in private sectors. The remaining respondents are working in government sector (24.3\%) or self-employed (25.1\%).

\section{Judgment Creditor and Judgment Debtor by Monthly Income}

Nearly half (43.4\%) of the judgment creditors have a monthly income below RM1000. This is followed by those with monthly income between RM1000-RM2000 and RM2001-RM3000 at 29.0\% and 17.1\% respectively. On the other hand, more than one third (33.3\%) of the judgment debtors have their monthly income between RM1001-RM2000 formed. This is followed by the monthly incomes between RM2001RM3000 (18.5\%). There are also 16\% of them who have a monthly income below RM1000. In addition, there are a small number of judgment debtors who have a monthly income RM6001 and above but also failed to maintain their obligation to pay for the maintenance. Their distribution is represented by 11 judgment debtors or $13.5 \%$. 


\section{Judgment Creditor and Judgment Debtor by Dependant}

Nearly one-third (30.1\%) of the total judgment creditors have three children followed by judgment creditors who have two children (22.8\%). The amount is only slightly more than judgment creditors who have five and more children (20.6\%). Meanwhile, for the judgment debtors, more than one third $(29.0 \%)$ of them have three children, followed by the judgment debtor who have two and five children. This is represented by $22.5 \%$ and $21.4 \%$ respectively.

\section{Judgment Creditor and Judgment Debtor by Marital Status}

Majority of judgment creditors are widows (91.6\%) and not remarried after divorce. Only a small number of them (7.6\%) who remarried after divorce. The same goes to the judgment debtor. Majority of the judgment debtors are widower (84.0\%) and only one-third (16.0\%) of them remarried after divorce.

\section{Nature of Maintenance Order}

The nature of the court order by type of order refers to the order given through ex parte, mutual consent, interim order or court intervention.

Table 2

Nature of the maintenance order

\begin{tabular}{|l|r|r|}
\hline \multicolumn{1}{|c|}{ Nature of the maintenance order } & Frequency & \multicolumn{1}{c|}{ Percentage } \\
\hline Others (no order given) & 2 & 0.6 \\
\hline Interim order & 7 & 2.0 \\
\hline Ex-parte order & 44 & 12.4 \\
\hline $\begin{array}{l}\text { Order with the appearance } \\
\text { Of both }\end{array}$ & 123 & 34.6 \\
\hline Mutual consent order & 179 & 50.3 \\
\hline Total & $\mathbf{3 5 5}$ & $\mathbf{1 0 0}$ \\
\hline
\end{tabular}


More than half of the enforcement and execution cases analyzed are an order derived from the mutual consent agreement (50.3\%). It seems that the mutual agreement before the order cannot be a mechanism to ensure that the order will be followed and the payment will be made. The nature of the court orders appear to be the important factors in determining that the judgment debtor will comply with the order and the most appropriate mechanism should be used for.

\section{Classification of Payment}

For the order of payment, there are two types of payment namely the regular and arrear payment. Besides viewing the forms of payment, based on the distribution of regular and arrear payment, the discussion details the pattern on the amount of each types of payment. The payments made are either for regular or arrear payment. Payment of certain sums was made by various channels and methods to facilitate the judgment debtor and judgment creditor. Existing facilities provided were in line with the provisions enacted. Classification of payment is as showed in Table 3.

Table 3

Classification of payment

\begin{tabular}{|l|r|r|}
\hline \multicolumn{1}{|c|}{ Type of payment } & Frequency & Percentage \\
\hline Regular payment & 194 & 54.6 \\
Both & 128 & 36.1 \\
\hline Arrear payment & 33 & 9.3 \\
\hline Total & $\mathbf{3 5 5}$ & $\mathbf{1 0 0}$ \\
\hline Amount of payment (RM) & & \\
\hline Regular payment & 13 & 8.0 \\
\hline 30 to 100 & 112 & 68.7 \\
\hline 101 to 500 & 23 & 14.1 \\
\hline 501 to 1000 & 15 & 9.2 \\
1001 to 5000 & $\mathbf{1 6 3}$ & $\mathbf{1 0 0}$ \\
\hline Total & & 2.5 \\
\hline Arrear payment (RM) & 8 & 7.5 \\
\hline 100 to 500 & 24 & 63.0 \\
\hline 501 to 1000 & 203 & 22.7 \\
\hline 1001 to 10000 & 73 & 2.8 \\
\hline 10000 to 50000 & 9 & 1.6 \\
\hline 50001 to 100000 & 5 & $\mathbf{1 0 0}$ \\
\hline 100001 to 200000 & $\mathbf{3 2 2}$ & \\
\hline Total & & \\
\hline
\end{tabular}




\begin{tabular}{|l|r|r|}
\hline Channel of Payment & & \\
\hline Bank in & 152 & 42.8 \\
\hline Not specified & 135 & 38.0 \\
\hline Attachment of the salary & 30 & 8.5 \\
\hline By hand & 24 & 6.8 \\
\hline Via third party & 9 & 2.5 \\
\hline Via court & 5 & 1.4 \\
\hline Total & $\mathbf{3 5 5}$ & $\mathbf{1 0 0}$ \\
\hline Method of Payment & & \\
\hline Monthly payment & 212 & 59.7 \\
\hline Not specified & 96 & 27.0 \\
\hline Installment & 39 & 11.0 \\
\hline Lump sum & 8 & 2.3 \\
\hline Total & $\mathbf{3 5 5}$ & $\mathbf{1 0 0}$ \\
\hline
\end{tabular}

\section{Type of Payment}

More than half of the data (54.6\%) are to enforce the arrear payment. Only $9.3 \%$ cases are to enforce the regular payment. On the other hands the total cases, which constitute both regular and arrears payment are 128 cases (36.1\%). It is found that, most of the applications made through judgment debtor summon are to enforce the arrear payments, whereas under the code of 034 (application for the execution of the court order) and code 033 (Application for the enforcement of maintenance orders) are to enforce the regular payment.

\section{Most Recent Amount of Payment}

\section{i. Most Recent Amount of Regular Payment}

The most recent amount of the regular payment shows the wide range of amount. The amount in the range of RM101 to RM500 achieved the highest frequency which is more than half (68.7\%) of the data. Followed by the amount of RM501-RM1000 at 14.1\%. Whereas the lowest amount (RM30 to RM100) and second lowest (RM1001 to RM5000) are at 9.2\% and $8.0 \%$ respectively. 


\section{ii. Most Recent Amount of arrears payment}

Similar to the most recent amount of regular payment, the most recent amount of arrears payment also shows that there is a wide range of arrears payment from the smallest amount to the biggest. It depends on the cases. More than half (63.0.6\%) of the arrears payment amount more than RM1000 to RM10,000. This was followed by the amount of RM10,000 to RM50,000 and the amount of RM501-RM1000 in the second and third stage. The percentages of both are at $22.7 \%$ and $7.5 \%$ respectively.

\section{Channel of Payment}

Channel of payment refers to the place where the payment should be made. The most popular channel was through bank-in, which represents more than one third $(42.8 \%)$ of the cases. It is noteworthy to find that more than one third (38.0\%) of the cases are not specified through the bank-in channel of payment. It seems the channel of payment should solely depends on the judgment debtor and judgment creditor.

\section{Method of Payment}

More than half (59.7\%) of the cases choese monthly payment as their method of payment followed by installment at $11.0 \%$. Moreover, a small percentage of the cases chose the lump sum method to pay the arrears maintenance. The monthly installment or lump sum method depend on the type of payment whether regular or arrear payment. Most of the regular payments were made using monthly payment while the arrears uses installment method. Similar to the channel of payment, the data also indicates that nearly one third (27.0\%) of the orders did not determine the method of payment when the judgment was given. 


\section{Reason and Duration of Application of Enforcement and Execution of the Court Order}

Basically, the enforcement and execution of a maintenance order is made because the voluntary payment did not happen. However, when the implementation or enforcement application is made, a variety of reasons were put forward by the applicant in providing justification as to why such action should be made.

\section{Reason for Application}

The reason for the application might also be a reason for the noncompliance of the court order. However, the reason for the non-compliance behaviour is too diverse and cannot be specified. For instance, in the strictest sense, fathers or ex husbands are in default if they miss a schedule according to the order or agreement. However, there is a diversity of payment patterns ranging from full and consistent compliance to near or total non-compliance. For this study, the reasons are divided into five types, namely:

i. $\quad$ Failure to pay the maintenance order,

ii. The payment does not follow the order,

iii. There was irregular payment,

iv. The undetected judgment debtor, and

v. The payment was made once only.

The reasons for the application are shown below in Table 4 .

Table 4

Reason for application of enforcement and execution of maintenance order

\begin{tabular}{|l|r|r|}
\hline \multicolumn{1}{|c|}{ Reasons } & \multicolumn{1}{c|}{ Frequency } & \multicolumn{1}{c|}{ Percentage } \\
\hline Not following the order & 172 & 52.8 \\
\hline Failure to pay the maintenance order & 126 & 38.6 \\
\hline Irregular payment & 19 & 5.8 \\
\hline Pay once only & 9 & 2.8 \\
\hline Undetected judgment debtor & 2 & 0.6 \\
\hline Others (e.g.: employers refuse to deduct the salary) & 7 & 2.1 \\
\hline Total & $\mathbf{3 2 6}$ & $\mathbf{1 0 0}$ \\
\hline
\end{tabular}


The data indicates that almost half of the applications (52.8\%) are due to the judgment debtor not following the order. This was followed by the reason of never paying the maintenance order at 38.6\%. Another reason stated were irregular payment, pay only once and undetected judgment debtor. All these reasons formed at percentage of 5.8\%, 2.8\% and $0.6 \%$ respectively.

\section{Duration of Application}

The data indicates that almost half of the applications (52.8\%) are due to the judgment debtor who was not following the order. This was followed by the reason of failure to pay the maintenance order at 38.6\%. While for another reason such as irregular payment, pay one time only and undetected judgment debtor and others are in the small percentage which are $5.8 \%, 2.8 \%, 0.6 \%$ and 2.1 respectively.

The following Table 5 illustrates the duration of the application taken after the judgment.

Table 5

Duration to register for enforcement and execution

\begin{tabular}{|l|r|r|}
\hline \multicolumn{1}{|c|}{ Duration } & Frequency & \multicolumn{2}{c|}{ Percentage } \\
\hline 1 month & 6 & 1.7 \\
\hline 2 months to 1 year & 119 & 33.5 \\
\hline 1 years to 5 years & 162 & 45.6 \\
\hline 6 years to 10 years & 55 & 15.5 \\
\hline 11 years to 20 years & 13 & 3.7 \\
\hline Total & $\mathbf{3 5 5}$ & $\mathbf{1 0 0}$ \\
\hline
\end{tabular}

More than one-third (45.6\%) of the cases are registered between 1 year to 5 years from the time when the judgment was given. This was followed by a period of 2 months to 1 year (33.5\%). Whereas between 6 to 10 years is $15.5 \%$. There are a small number of cases (3.7\%) which took 11 to 20 years to register. Similarly for registration within 1 month which is only $1.7 \%$. 


\section{Court Proceeding to Enforce and Execute the Court Order}

The enforcement mechanism and effective execution of the order depend on the ability of the parties to follow the right procedure and process. In addition, a non administrative action before the court process also increases the percentage of compliance to the court order. This process needs to be settled before the proceeding. Table 6 shows the process taken before and during the proceeding of enforcement and execution of legal action.

Table 6

Enforcement and execution process

\begin{tabular}{|c|c|c|}
\hline Processes (N=355) & Frequency & Percentage \\
\hline Summon & 303 & 85.4 \\
\hline Notice of Appearance & 288 & 81.1 \\
\hline Mediation & 149 & 42.1 \\
\hline Judgment Debtor Mean Test & 62 & 17.5 \\
\hline Warrant of Arrest & 36 & 10.2 \\
\hline
\end{tabular}

*multiple response

\section{Summons}

A suummons is a court order to an individual to appear in court at a specified place and time. ${ }^{15} \mathrm{~A}$ summons must be served to the judgment debtor before or during the seven days of the first hearing. ${ }^{16}$ A summons could be delivered to the respondent either through delivery service of the court or law firm notice server (Penghantar Notis). Also, it can be delivered via post and district office (Pejabat Daerah) services.

The data indicates that the majority of the cases reviewed (85.4\%) have succeeded to serve the summons to the judgment debtor. The rest (14.6\%) summons could not be delivered to the judgment debtor for

$15 \quad$ Elizabeth a Martin, Dictionary of Law, 1994, Third Edition (New York, Oxford University Press, 1994), at 359.

16 Syariah Court Civil Procedure (Federal Territories) Act Section 45. 
several reasons such as changed of judgment debtor's workplace, residence and address missing info.

\section{Notice of Appearance}

For many cases, even though the summons could be delivered, it is often that the judgment debtor failed to appear during the hearing/trial without any specific reason. The judgment creditor would request for notice of appearance. Similar to the process of serving a summons, notice of appearance would also be served to judgment debtor before or during seven days of the first hearing.

The data shows that the majority of the cases (81.1\%) have succeeded to serve a notice of appearance to the judgment debtor. In the rest (18.6\%) of the cases this could not be delivered.

\section{Mediation}

Mediation or sulh is a pre-condition to the trial process. It is assumed to be successful when the parties have reached a consensus that will be recorded, and the record is brought before a judge for his endorsement. ${ }^{17}$ Mediation or the sulh process is vital for the settlement of any claims in the Syariah Court.

However, the data indicates that only 148 of the enforcement and execution cases went for the mediation or sulh process compared to the non-mediation process $(57.7 \%)$. It is presumed that the judgment creditors have no interest to go for the mediation or sulh process since most of the judgments are granted by way of mutual consent. Furthermore, in most cases, the judgment debtor could not be detected and the mediation session, requiring the appearance of both parties, could not be held.

$17 \quad$ Raihanah Azahari, "The Development of Family Mediation in Malaysian Muslim Society,” (2010), European Journal of Social Sciences, Volume 18, Number 2. 


\section{Judgment Debtor Means Test}

In certain cases, if the payer can show a reason for the inability to make the payment ordered, the court has the power to allow variation of payment with the consent of the payee. However, in order to get clear information on the capability of the judgment debtor, the judgment debtor means test should be done properly.

The data indicates that less than one-fifth (17.5\%) of the cases had applied a judgment debtor means test during the proceedings. One of the reasons behind this occurrence is disappearance of the judgment debtor. Since the examination was not conducted during the trial, the judgment debtor summons relies only on the judgment creditor's evidence; and in certain cases, the court just validated the amount of debt without any concrete evidence.

\section{Warrant of Arrest}

Only 36 cases had applied for warrant of arrest. The small number using warrant of arrest significantly shows that it is unpopular in the case of enforcement and execution of the maintenance order.

\section{Judicial Decision in Enforcement and Execution of Maintenance Order Cases}

This subsection lays out the pattern of judicial decisions delivered by the Syariah Court. It provides the type of judgment and duration of case settlement. ${ }^{18}$ (Table 7). 
Table 7

Judicial Decision in Enforcement and Execution of Maintenance Order Cases

\begin{tabular}{|l|r|r|}
\hline \multicolumn{1}{|c|}{ Type of Judgment } & Frequency & \multicolumn{2}{c|}{ Percentage } \\
\hline Approved & 187 & 52.5 \\
\hline Withdrawal & 81 & 22.5 \\
\hline Consent order & 36 & 10.1 \\
\hline Strike out & 36 & 10.1 \\
\hline Dismissed & 7 & 2.0 \\
\hline Variation & 4 & 1.1 \\
\hline Remained & 1 & 0.3 \\
\hline Others (e.g.: no judgment given) & 4 & 1.1 \\
Total & 355 & $\mathbf{1 0 0}$ \\
\hline Duration (Months) & & 63.4 \\
\hline Below 6 & 225 & 19.7 \\
\hline $7-12$ & 70 & 12.9 \\
\hline $13-24$ & 46 & 4.0 \\
\hline 25 and above & 14 & $\mathbf{1 0 0}$ \\
\hline Total & $\mathbf{3 5 5}$ & \\
\hline
\end{tabular}

\section{Type of Judgment}

Almost half of the cases (52.5\%) brought to the court were approved by the judges. It is followed by the withdrawal of cases (22.5\%). In addition, one-fifth of the cases (10.1\%) ended up by consent order and by striking out by the court. However, in some cases where the judgment debtor cannot be detected, the court will still award the approval for the application. The approval given was to verify the amount of arrears payment. It seems that the court will just make a repetition on the same process of application for the maintenance orders.

\section{Duration of Case Settlement}

More than half of the cases (63.4\%) were settled within 6 months or less. This was followed by 7 to 12 months at $19.7 \%$, whereas 46 cases 
or $12.9 \%$ were settled between 13 to 24 months. The only $4.0 \%$ of the cases were settled in more than 25 months.

\section{DISCUSSION AND CONCLUSION}

Based on Section 133-134 of the Syariah Court Civil Procedure (Federal Territories) Act 1998 (SCCPA), types of enforcement and execution used by the judgment creditor can be made using the following methods:

i) Enforcement Order;

ii) Seizure and Sale Order;

iii) Ownership Order;

iv) Transfer of Ownership Order;

v) Hiwalah (Garnishment or, Transference of Liabilities) Proceeding;

vi) Judgment of Debtor Summon;

vii) Committal Proceeding;

viii) Attachment of salary.

It is found that the determination of the method of payment will indeed expedite the process of implementation and enforcement of maintenance orders. Even though this action has no significant correlation to the non-compliance, but practically once the method of payment has been determined, the application would then be easier. From the observation made, some of the cases are only there to justify the channel or method of payment. Thus, in granting the order to the judgment creditor, the task of judges is not just to ensure whether the order should or should not be given on the evidence adduced, but the judge has the duty to ensure that the order could be implemented and executed. Hence, justice can be fully achieved.

From this research it is found that more than half of the enforcement and execution cases are an order derived from the mutual consent agreement. This finding shows that the possibility to end the process earlier or one way to escape from court proceedings might be the reason for the agreement being made. Even the research on Sulh application in the Syariah Court has revealed that sulh managed to shorten 
the time and early settlement could be made ${ }^{19}$ but the result did not promise that the agreement would be complied with. Conversely, the ability of willingness to pay, is an important factor to improve the judgment debtor's adherence to the court order. Further, more than one-third of the orders (34.6\%) are the orders granted in the appearance of both parties. This means that the full trial proceeding has been reached and the judgment given were based on the evidence submitted by both parties. The reason was stated on the judgment creditor's application form. The term "not following the order" referred to the pattern of judgment debtor's payment, which is usually the amount that was smaller than the amount ordered. From this finding, it is presumed that the unwillingness to pay contributed more for this reason. In addition, there are cases of applications made by employers who do not or refuse to abide to the attachment of the salary. Sometimes the judgment debtor has stopped working or has changed his work place in order to run away from his obligation.

The longer the time taken to register a case, the larger the amount of arrears payment. The amount increases the disability of the judgment debtor to pay the debt. For instance, the longest time recorded was the order obtained in 1986 and only registered for enforcement and execution action in the year 2006 with the total claim of RM78296.00..$^{20}$ This case took 20 years to register. The amount was paid through Hiwalah proceedings. The action was registered under the code of 034 , which is under the code of execution of the maintenance order. However, in their affidavit the action mentioned that it was a Hiwalah proceeding. The third party (Amanah Raya Berhad) as the trustee for the judgment debtor's property made the payment. In this action, it was found that the judgment debtor / respondent was no longer working and failed to make payments until the arrears of maintenance has reached RM78,296. The payment was obtained through this action; the money was from the judgment debtor's late son who had passed away, and the compensation was given to the judgment debtor as one of the faraid receiver.

\footnotetext{
19 Raihanah Hj Azhari,, "Sulh Dalam Perundangan Islam Kajian di Jabatan Kehakiman Shariah Selangor,” (Ph.D Thesis, University of Malaya, 2000).

$20 \quad$ Case No.: 14100-034-0214-2006 (Suriah Daud VS Wan Abdullah Haji Wan Hamat).
} 
It is noteworthy to find that on average, the judgment creditor takes only seven months up to one year prior to hand in the application of enforcement and execution of the order to the court. Usually, a period of three months ${ }^{21}$ is given to the judgment debtor after the order for maintenance is granted before taking action for the enforcement of the order.

Similar to the summons process, reasons for undelivered notice of appearance are change of judgment debtor's workplace, change of residence and unknown address. However, since the establishment of the Family Support Division Unit in every Syariah Court in Malaysia, summons and notice of appearance are being handled through this unit. In most cases of the enforcement and execution of a maintenance order, the service of the summons and notice of appearance becomes difficult to serve if the address of the judgment debtor is not known. This usually happens in cases where the order is obtained without his appearance (ex-parte). ${ }^{22}$

Naturally, in certain cases, the judgment debtor resists presenting himself to the court even when the summons and notice of appearance had been served. Alternatively, the warrant of arrest is used as the last option for the court to force the judgment debtor to appear before the court, when voluntary appearance could not be made. For most cases, the execution of a warrant of arrest becomes a typical problem. This is due to not being able to get full cooperation from enforcement agencies such as the police and syariah enforcement officers. Furthermore, the respondents' actions', namely those who had fled and their whereabouts could not be detected have increased the problems.

Usually, the judgment creditor will withdraw the case voluntarily if the judgment debtor's whereabouts cannot be detected. Similarly, the debtor's whereabouts is one of the reasons for the cases to be struck out or dismissed. Sometimes the court will dismiss the cases when the

$21 \quad$ Three months is the period which is usually given by the judgment creditor and the lawyer in order to ensure voluntary compliance by the judgment debtor. If after three months has passed and the judgment debtor has yet to comply with the maintenance order, legal action will be initiated by the judgment creditor against the judgment debtor.

22 Interview with FSD officer, En Hairuddin Bin Abdul Rahman on 22th November 2011. 
judgment creditor fails to appear before the court without any particular reason.

Similar to maintenance cases, the duration of the case settlement actually cannot reflect the compliance of the court order. Nevertheless, it will reflect the efficiency of management in the court cases. This also indicates that the court has fulfilled the requirement for Syariah Court key performance indicator, which in the case, must reach the duration of settlement within 180 days. As in any other family cases such as divorce cases, (Siti Zubaidah, et al 2011) the major reason for delays came from the judgment creditor or the judgment debtor itself. However, for the enforcement and execution cases, the problem regarding execution summons and warrant of arrest also became the most raised issues for the delays. To conclude, the study revealed that the nature of the court order is crucial in determining the mechanism of the enforcement and execution. It was found that many orders issued by the court did not state the channels and methods of execution, especially those involving the payment of money orders. The study also found out that although the order obtained was based on mutual agreement between the parties, it does not constitute a guarantee that the order will be complied with by the parties. Thus, court players have their own roles in the success of the enforcement action. The study also found out that regardless of any mechanisms used to implement and enforce the maintenance order of the Syariah Court, the parties, especially with the cooperation of the judgment debtor is able to accelerate the solution process of enforcement of maintenance orders in the Syariah Court. Pertaining to the duration of case settlement, it has achieved the key performance indicator set up by the government which is not more than 180 days. However, there are a small number of cases that dragged up to more than 12 years. Overall, the study shows that an effective mechanism for the enforcement and execution of the order does not only depend on the legal process alone but also must have a strong assimilation between legislative and administrative action. 